\title{
Hvordan har vi det i dag?
}

\section{Flere perspektiver på måling af mental sundhed hos born og unge}

\section{Carsten Obel ${ }^{1}$, Kathrine Bang Madsen², Signe Herbers Poulsen ${ }^{3} \&$ Katrine Svendsen ${ }^{4}$}

\author{
Aarhus Universitet \\ ${ }^{1}$ co@ph.au.dk \\ ${ }^{2}$ kathrine.bang@econ.au.dk \\ ${ }^{3}$ signe.h.poulsen@ph.au.dk \\ ${ }^{4}$ kasv@ph.au.dk
}

Obel, Carsten; Madsen, Kathrine Bang; Poulsen, Signe Herbers; Svendsen, Katrine (2018). ‘Hvordan har vi det i dag? Flere perspektiver på måling af mental sundhed hos børn og unge', Tidsskrift for Forskning i Sygdom og Samfund, nr. 29, 15-26

Unge $i$ dag er fra tidligt $i$ barndommen blevet vannet til at blive spurgt om, hvordan de har det. Forældrene spurgte, når de blev hentet i børnehave, de bliver spurgt af forskerne, af undervisningsministeriet, og de spørger derfor også tit sig selv. Historien om at have det godt eller skidt er det centrale omdrejningspunkt for kommunikationen om trivsel både i pressen, på de sociale medier og $i$ samfundet $i$ øvrigt og er med til at skabe en uhensigtsmæssig bekymringskultur. Denne hedoniske, selvcentrerede tilgang var moderne $i$ 'well being'-forskningen for et halvt århundrede siden, men givet den mellemliggende udvikling $i$ forstålsen af mental sundhed er der grund til at udfolde begrebet med andre perspektiver og udvikle et frlles sprog for mental sundhed. I artiklen argumenterer vi med udgangspunkt $i$ resiliens-tilgangen for, at der er behov for at flytte fokus fra egen umiddelbare tilfredsstillelse til at vurdere børn og unges funktion i forskellige sociale kontekster. Vi understreger samtidigt nødvendigheden af, at styrke børn og unges robusthed ved at udsætte dem for mindre mængder af stress gennem opvaksten indenfor kontrollerede rammer. Oplevelser 
med meningsfyldt stress kan fungere som en mental pendant til børnevaccination og ruste dem til fremtidens udfordringer.

How are we today? Different perspectives on the measurement of mental health of children and adolescents

Today, young people are used to being asked how they are (feeling). The parents would ask them when picking them up from nursery, researchers as well as the Ministry of Education are asking them, and often they ask themselves. Feeling good or bad is the central focal point for communicating about well-being in the press, social media and in society as a whole which might lead to a culture of unnecessary worry. This hedonistic self-centered approach was modern in the 'well being' research half a century ago, but given the intermediate development in the understanding of mental health, there are reasons to develop the concept and to work on a common understanding. In this article we argue for the use of the resilience approach to widen the focus from self-centeredness to an assessment of the function of the child in different social settings. Additionally, we emphasise the need to strengthen the resilience of children and young people through the exposure of small amounts of stress during childhood in a controlled setting. This might serve as a mental counterpart of the traditional child vaccinations.

\section{Indledning}

"Hvordan har vi det i dag?" Sådan spurgte overlægen patienten i det forrige århundrede, når han stod ved fodenden af patientens seng ved stuegang på hospitalet. Han talte typisk ikke direkte til patienterne. Den gamle læges argument var måske, at de ikke skulle bekymre sig, men have ro til at komme sig. Der var ikke den store inddragelse af patienten, og det medicinske paradigme havde fokus på lægens autoritative monopol på at vide bedst. Det var en praksis, der var gældende helt frem til 1960'erne. Siden er der sket store ændringer i læge-patient-forholdet, og i dag forventes det, at lægen kommunikerer direkte og mere ligeværdigt med patienten. De fleste patienter vil på stuegang blive spurgt direkte: "Hvordan har du det i dag?". En god læge vil imidlertid aldrig alene stole på patientens egen vurdering, men sammen med sin 'objektive vurdering', som typisk baserer sig på en systematisk undersøgelse, inddrage patientens subjektive svar i sin samlede vurdering af patientens tilstand. Udviklingen inden for sundhedsområdet med at inddrage patienternes opfattelse af og tilfredshed med behandlingsforløbet har 
taget en meget positiv udvikling, og inden for de sidste årtier er de såkaldte Patient Reported Outcome Measures (PROM) ${ }^{1}$ blevet en vigtig del af kvalitetsvurderingsprocessen i sundhedsvæsenet, som stadig udvikler sig i retning af mere involvering af patienten. Det er en udvikling, der har ført meget godt med sig, men der er ingen tvivl om at hvis man hele tiden spørger patienten, hvordan han eller hun har det, kan det nemt føre til bekymringer hos ham eller hende. Der kunne også opstå tvivl om, hvorvidt der er styr på behandlingen, eller om man på anden måde er usikker på, hvad det er man foretager sig for at hjælpe dem.

Det er i samme periode, at tidligere tiders autoritære børneopdragelse er under forandring og man begynder at se anderledes på børn, prioritere deres trivsel på en ny måde og spørge ind til deres subjektive følelse af velbefindende. Samtidigt kommer begge forældre på arbejdsmarkedet i 1970'erne. Indtil da blev de fleste børn passet hjemme, og deres mor kunne som regel se, hvordan de havde det. Med børnene i daginstitutioner adskilt fra deres forældre i mange timer fulgte et større fokus på at spørge aktivt ind til deres trivsel. Det er en udvikling, der er fortsat de seneste årtier og det er blevet en naturlig del af hverdagen, at de voksne spørger meget ind til, hvordan børn og unge har det. Men måske kan alle de spørgsmål have en modsatrettet konsekvens. Måske har vi som forældre og fagfolk været for optagede af at spørge de unge på en uhensigtsmæssig måde og derigennem været medvirkende til at overføre en "bekymringskultur" til dem i forhold til deres trivsel? Måske har vi samtidigt haft et for stort fokus på generelle trivselsmålinger målrettet børn og unge og for lidt fokus på at skabe forebyggende rammer og robusthed samt systematisk opfølgning på observationer fra fagpersoner og andre voksne omkring barnet/den unge?

\section{Hvordan har børn og unge det i dag?}

At understøtte danske børn og unges mentale sundhed og trivsel er en vigtig samfundsmæssig opgave. Den mentale sundhed har stor betydning for det enkelte barns læring og udvikling, og er udgangspunktet for at vores børn og unge får de bedste muligheder for at udvikle deres potentiale og bidrage til samfundet (Beddington et al., 2008). Der vil i fremtiden være tiltagende store samfundsudfordringer at løse for de unge. Den demografiske udvikling går mod en stadig større andel af ældre i befolkningen og færre unge i den arbejdsdygtige alder. I befolkningsfremskrivninger fra Danmarks Statistik anslås det, at hver fjerde dansker vil være 65 år eller ældre i 2040 (»Danmarks Statistik. Statistikbanken. „« 2017). Der 
er behov for at de færre unge borgere skal være særligt mentalt sunde, robuste og innovative, hvis de skal kunne løfte de samfundsmæssige arbejdsopgaver, som denne udvikling i demografi sammen med et stadigt hurtigere omskifteligt samfund kræver. Derfor giver det anledning til bekymring, at mange undersøgelser samstemmende fortæller en historie om, at nutidens unge har mere stress, er mere triste og oplever en lavere grad af livstilfredshed (Due et al., 2014).

En rapport fra Vidensrådet for forebyggelse fra 2014 viste en stigning i andelen af unge, som rapporterer, at de ikke trives. De føler sig blandt andet mere ensomme og mindre tilfredse med livet (Due et al., 2014). Skolebørnsundersøgelsen, der udføres hvert fjerde år, viste i 2014 en særlig markant ændring for de 15-årige, hvor der er sket et betydeligt fald i andelen af både piger og drenge med høj livstilfredshed (Rasmussen M, 2015).

Denne udvikling er sket til trods for, at danske børn og unge sammenlignet med tidligere tiders fattigdom, ulighed, autoritære opdragelse og skolegang burde have meget bedre muligheder for et godt liv end tidligere. Samtidigt har de også langt bedre forhold end unge i mange andre lande, bl.a. fordi de lever i et demokratisk samfund med et trygt velfærds- og sundhedssystem. Danske unge bor tilmed $\mathrm{i}$ et land, hvor befolkningen ligger $\mathrm{i}$ top, når det kommer til målinger af lykke (Helliwell J, 2017).

Selvom at vi har spurgt de unge mange gange, er vi kun i begrænset grad blevet klogere på, hvad årsagerne til børn og unges selvrapporterede forringede livskvalitet er. Det eneste, som vi er ret sikre på er, at det er komplekst og et samspil af en række forskellige årsager. Vi ved at samfundet ændrer sig hurtigere end tidligere, og at en række af disse ændringer gennem de seneste årtier kan have indflydelse på det sociale stress niveau og de unges trivsel. En omskiftelig verden med en øget individualisering og et skarpere fokus på individuelle præstationer samt et generelt større forventningspres kan have betydning. PISA-undersøgelser og hyppige nationale tests i folkeskolen bidrager til denne udvikling, og der er stor bevågenhed på at sammenligne danske unges faglige niveau med niveauet $\mathrm{i}$ andre lande med henblik på at sikre Danmarks fremtidige konkurrenceevne. Samtidig udvikler samfundet sig hurtigere end tidligere, hvilket indebærer mange valgmuligheder og en usikker fremtid for de unge. En stigende brug af sociale medier med en kultur og deraf følgende pres for at fremstå perfekt har uden tvivl også betydning. Hertil kommer en udvikling i forståelsen af befolkningens sundhed, som ikke kun har fokus på KRAM-faktorer (kost, rygning, alkohol og motion), men hvor mental sundhed også betragtes som central for vores evne til at producere og bidrage til samfundet (Eplov LF, 2008). Indtil videre har konsekvensen 
af dette øgede fokus primært været på at forsøge at måle og dokumentere trivsel, men spørgsmålet er hvad mental sundhed er? Og hvordan vi bedst løbende monitorerer og forbedrer den?

\section{Definition af mental sundhed}

Lad os starte med at indkredse, hvad vi forstår ved mental sundhed. Der har siden 60'erne tegnet sig to hovedretninger inden for forskning og teoridannelse om mental sundhed (Waterman, 1993). Det hedoniske perspektiv var fremherskende i 60'er og 70'erne og har fokus på lykke, tilfredsstillelse og tilfredshed med livet (en tilstand af velbefindende). I dette perspektiv er fokus på tilstedeværelsen af positive elementer i livet og fraværet af negative. Det eudaimoniske perspektiv udviklede sig gennem 80'erne og 90'erne med mere fokus på glæden ved at udvikle sit potentiale. Her beskæftiger man sig med den særlige menneskelige evne til at forfølge komplekse mål, som er meningsfulde både for individet og samfundet. I den eudaimoniske dimension ligger altså et socialt bidragende element sammen med vigtigheden af at føle et tilhørsforhold. Den amerikanske psykolog og sociolog Corey Keyes, som har været en af de toneangivende i forhold til at konceptualisere forskellige dimensioner af mental sundhed, argumenterer for, at det hedoniske og det eudaimoniske perspektiv tilsammen udgør positiv mental sundhed (Westerhof \& Keyes, 2010). Han skelner mellem flourishing, som en tilstand hvor individet har et højt niveau af subjektivt velbefindende sammen med et højt psykologisk og socialt funktionsniveau, og languishing, som betegner det modsatte - en mental udtrætning (Keyes, 2002).

Disse perspektiver finder vi også i den internationalt anerkendte definition udviklet af WHO (World Health Organization), hvor mental sundhed defineres som:

"En tilstand af velbefindende, hvor et individ er $i$ stand til at udfolde sit eget potentiale, kan håndtere dagligdagens udfordringer, kan arbejde produktivt samt kan bidrage positivt til samfundet" (WHO, 2014).

Som det fremgår, rummer definitionen to overordnede dimensioner: En oplevelsesdimension og en mere funktionsorienteret dimension. Det indebærer, at børn og unges mentale sundhed ikke alene defineres ud fra, hvordan de føler de har det, men ud fra en række andre perspektiver, som også handler om social interaktion og håndtering af eget liv. 
Uanset en formel enighed om denne definition f.eks. mellem sundhedsstyrelsen og undervisningsministerium har selve operationaliseringen af den i praksis vist sig at være kompleks - og ikke mindst i hvordan vi måler mental sundhed?

\section{Målinger af børns mentale sundhed i Danmark}

Der er de seneste år blevet foretaget flere undersøgelser af børn og unges mentale sundhed, herunder Skolebørnsundersøgelsen (HBSC) (Rasmussen M, 2015), Ungdomsprofilen (Bendtsen P, 2015), "Alle unge tæller"(Lindholdt L, 2017), Ungeprofilundersøgelsen (»Ungeprofilundersøgelsen, « 2017) samt Folkeskolens Trivselsmåling (»Folkeskolens Trivselsmåling, « 2016). Mange af undersøgelserne og diskursen omkring dem har fokus på særligt den hedoniske dimension i måden, hvorpå vi omtaler og bekymrer os om, hvordan børn og unge har det. Vi har primært fokuseret på, om de er tilfredse med deres liv, mens vi i mindre grad interesserer os for, hvordan børnene og de unge håndterer deres liv og bidrager meningsfuldt i de sammenhænge de indgår i. Det gælder især i uddannelsessystemet, hvor alle elever årligt er blevet stillet spørgsmål om, hvordan de har det i Folkeskolens Trivselsmåling.

Undersøgelserne bidrager med vigtig viden i forhold til at dokumentere og belyse udviklingen i børn og unges mentale sundhed over tid. Ikke desto mindre bidrager mængden og hyppigheden af dem samtidigt til en bekymringskultur, der er med til at forstærke opmærksomheden på mental sundhed på en uhensigtsmæssig måde og i sidste ende kan virke som et benspænd for den gode trivsel.

\section{"Åh nej, skal vi nu også have 12 i trivsel?" \\ - Elev, Akademiet for Unge Talentfulde i Region Midt 2017}

Ovenstående citat er et eksempel fra vores samarbejde med Akademiet for Unge Talentfulde og understreger, hvordan trivselsmålinger kan være med til at påvirke de unge. En myriade af undersøgelser og præstationsmålinger i kombination med et fritidsliv eksponeret på de sociale medier kan være svære at navigere i. Samtidigt resulterer denne form for undersøgelser i øjebliksbilleder af, hvordan børn og unge har det lige på det tidspunkt, de deltog i undersøgelsen, hvor mindre problemer kan fylde meget men hvor der også er en risiko for at overse alvorlige udfordringer. Enkeltstående dårlige oplevelser på legepladsen i foregående frikvarter eller aktuelle konflikter med venner eller familie kan dermed blive sty- 
rende for deres besvarelse af spørgsmålene. Ved at tage udgangspunkt i børnenes "her-og-nu-oplevelse" af hvordan de har det, risikerer man at fejlvurdere processer, der er krævende undervejs, men som er afgørende for børnenes udvikling og trivsel på længere sigt. Derfor er det også problematisk at anvende denne form for undersøgelser som et styreredskab eller til at planlægge og evaluere sundhedsfremmende indsatser. Det er umuligt at udtale sig om, hvad der ligger til grund for eventuelle forbedringer eller forværringer i målingerne, og vi ender i bedste fald med at implementere indsatser, der ikke virker. Her er der behov for langt mere kontrollerede og målrettede studier.

Samtidigt er der også en etisk udfordring i forhold til at gennemføre generelle undersøgelser, hvor man ikke hjælper de børn og unge, der rapporterer svære vanskeligheder. Til trods for, at hvert enkelt individ bliver adspurgt, præsenteres resultaterne af undersøgelserne i et så generelt og overordnet perspektiv, at de ikke bliver handlingsanvisende. Børn og unge kan dermed rapportere om svære udfordringer eller tegn på alvorlig mistrivsel, uden at deres svar udløser en adækvat handling eller hjælp. Hvis vi stiller spørgsmål om, hvordan børn og unge har det, har vi så ikke også en forpligtigelse til at handle individuelt på de svar, der kommer?

Der er således behov for at supplere de generelle temperaturmålinger med andre tiltag, der ikke kun spørger børn og unge om, hvordan de har det. Det er her resilienstænkningen byder ind med en forståelse, som måske 1) kan hjælpe os videre fra at fokusere alene på barnet/den unge til i højere grad at se på den sociale kontekst, som barnet/den unge indgår i, og 2) kan hjælpe os med at ruste børn og unge bedre til fremtidens udfordringer.

\section{Resiliens og den sociale kontekst}

Resiliens er i fysikken et mål for hvor meget et materiale kan stresses/strækkes og derefter genvinde sin oprindelige form. Som psykologisk mål har begrebet resiliens været anvendt synonymt med robusthed og blev som udgangspunkt udviklet med reference til individets evne til at komme godt igennem negative oplevelser i livet. Den tidlige resiliensforskning fokuserede primært på individuelle karakteristika hos børn, der trods svær modgang udviklede sig normalt (Fonagy et al., 1994), men de seneste år har resiliens tænkningen bevæget sig over i en mere multisystemisk forståelse af interaktionen mellem individet og dets omgivelser. Ligesom Bronfenbrenners udviklingsteoretiske arbejde bidrog til at skifte fokus 
fra det enkelte individ til betydningen af interaktionen mellem individ og miljø, har resiliensforskningen også bevæget sig væk fra undersøgelsen af det såkaldte "usårlige barn" til et fokus på de samfundsøkologiske faktorer, der faciliterer udviklingen af trivsel under stress (Ungar, 2011).

Ungars social-økologiske tilgang til resiliens understreger betydningen af systemiske faktorer. De påvirkninger det enkelte menneske udsættes for i samspillet med andre mennesker og miljøer påvirker dets udvikling. Det vil sige, at når mennesket udvikler sig, sker det altid i forhold til og under påvirkning af den sociale kontekst, det enkelte menneske er en del af. Det er mest meningsfuldt at se resiliens hos et individ som dynamisk, hvor individuelle faktorer sammen med de sociale netværk former individets resiliens gennem livet.

Et eksempel kunne være et barn med ADHD-vanskeligheder, der trives gennem en kombination af adfærdsmæssige og farmakologiske interventioner. Ændringer i barnets skoleklasse og bedre koordinering og strategier til håndtering af barnet mellem forældre og lærere kan påvirke barnet positivt. For at undersøge barnets mentale sundhed er det derfor nødvendigt at få belyst, hvordan barnet tilpasser sig skolemiljøet og hvordan barnets hjem og skole har tilpasset sig barnets behov (Ungar et al., 2013). Det er i denne henseende ikke tilstrækkeligt alene at spørge barnet/de unge. Der er også behov for at spørge de mennesker, som er sammen med barnet til daglig. Det giver et mere nuanceret indtryk af barnets funktion i hverdagen i de sociale kontekster, hvori barnet/den unge indgår, og eventuelt hvad der stresser den unge.

Spørger man en mor, en far, barnets lærere og pædagoger vil de ofte både se barnet forskelligt, se barnet i forskellige kontekster og samtidig have forskellige relationer til barnet. Det redskab, som internationalt set lige nu er mest veldokumenteret i forhold til at måle børn og unges mentale trivsel og funktion, er spørgeskemaet Strength and Difficulties Questionnaire (SDQ). Barnet samt de voksne, som er sammen med barnet i hverdagen besvarer den samme række af spørgsmål. Konsistensen og diskrepansen i besvarelserne danner grundlag for en kvalificeret tværfaglig dialog om barnets mentale sundhedstilstand og giver et billede af, hvor stor en rolle dets forudsætninger og sociale stresspåvirkninger er af betydning.

Vores erfaring fra de sidste mange års samarbejde med danske kommuner er, at man på denne ret enkle måde hurtigt kan danne sig et 360 graders perspektiv på barnets udfordringer, som gør at man langt hurtigere og mere kvalificeret kan hjælpe barnet. Men det er vigtigt at understrege at systematiske spørgsmål via spørgeskemaer ikke kan stå alene, hvis målet er at sikre at børn ikke mistrives. I Favrskov kommune har man i forbindelse med sundhedssamtaler med sundheds- 
plejersken en forudgående screening af, hvilke børn, der mistrives. Børn med en SDQ som tyder på mistrivsel tilbydes en samtale med sundhedsplejersken, som efterfølgende har et kvalificeret grundlag for en dialog med andre faggrupper i forhold til at give barnet den bedste hjælp. SDQ har vist sig at være et godt bidrag til udviklingen af et fælles sprog omkring mental sundhed og mistrivsel på tværs af faggrupper.

Hvis vi anerkender at dette er et vigtigt, men komplekst område, er det centralt, at vi stimulerer en dialog baseret på en fælles forståelse, vi kan acceptere på tværs af fagligheder som grundlag for en fælles refleksion over, hvad der bedst understøtter det udfordrede barn i særdeleshed og danske børn generelt. Det vil give en fælles systematik at arbejde ud fra og samtidig en fælles bevidsthed om, at der er behov for både flere videnskabelige discipliners bidrag, men også for en stærkere tværfaglighed i praksis.

\section{En mental børnevaccine, der ruster fremtidens unge}

Udover at være en psykologisk forståelse er resiliens også tæt forbundet med en biologisk forståelse af stresspåvirkning. Stress kan påvirke individet negativt, hvis den overbelaster og er vedvarende, og positivt hvis den er midlertidig (McEwen, 2016; Seery, 2011).

Vi er alle født uden sociale erfaringer, men forudsætningerne for vores udvikling er forskellig. Nogle er mere disponerede for sårbarhed end andre, mens nogle vil være mere robuste i forhold til det, de møder gennem livet. Samtidig udvikler og tilpasser vi os i et tæt samspil med vores omgivelser, hvilket betyder, at vi udsættes for noget forskelligt. Stress er her centralt, idet det biologisk kan ses som et tveægget sværd i forhold til vores udvikling og resiliens. Biologisk betegner stress alle påvirkninger, som aktiverer den biologiske stress akse (HPA) (Bremne \& Vermetten, 2001). Der er naturlig høj aktivitet om morgenen og fysiologisk reaktion på stress er helt central for en normal udvikling og således knyttet til en positiv neural udvikling. Det tveæggede består i, at langvarig stress kan have en række negative konsekvenser, som har negativ indflydelse på den neurale udvikling (McEwen, 2016).

Stress i få mængder er således ikke skadeligt, men kan faktisk være med til at ruste børn og unge. Det at få et godt liv rummer også evnen til at klare svære ting, og det er vigtigt at styrke udviklingen af denne hos børn og unge. Nogle forældre har pakket deres børn ind i en fortælling om, at solen altid skal skinne, og alt skal 
være godt hele tiden. Hvis man som barn eller ung aldrig har prøvet at håndtere modgang, kan det blive relativt svært at møde voksenlivet og skulle håndtere det at stå på egne ben og overkomme både de små og store udfordringer, der følger med. Det kan derfor være meningsfuldt, at forældre og fagfolk nogle gange presser barnet ud af dets komfortzone, så de løbende ruster sig til den mere ubeskyttede verden, de også skal agere i. Skal de blive mere kompetente, er det vigtigt, at man gør det - i passende mængder baseret på barnets ressourcer. Oplevelser med meningsfyldt stress kan fungere som en mental pendant til børnevaccination. Ved at give børnene en passende dosis under trygge omstændigheder, hjælper man dem til at udvikle et forsvar, når de møder udfordringer med fuld styrke senere i livet.

\section{Konklusion}

I denne artikel peger vi på, at det konstante og store fokus på børn og unges egen opfattelse af velbefindende i tidens mange trivselsmålinger kan være medvirkende til at overføre en "bekymringskultur" til dem. Samtidigt er det problematisk, at de generelle temperaturmålinger primært tager udgangspunkt i øjebliksbilleder og ikke hjælper de individuelle børn, der angiver mistrivsel. Derfor er der behov for flere perspektiver på arbejdet med mental sundhed. Med inspiration fra resiliens-tilgangen argumenterer vi for en systematisk tilgang til identificering af mistrivsel, der inddrager en vurdering af børn og unges funktion i forskellige kontekster med udgangspunkt i et fælles sprog, der kan anvendes på tværs af fagområder. Vi understreger samtidigt nødvendigheden af, at styrke børn og unges robusthed ved at udsætte dem for mindre mængder af stress gennem opvæksten indenfor kontrollerede rammer.

\section{Noter}

${ }^{1}$ Patient Reported Outcome Measures (PROM) henviser til patienters oplevede symptomer, funktionsevne og livskvalitet. 


\section{Referencer}

Arfman M, P.M., Bak PL, Obel C (redaktion). (2016). Ungeprofil undersøgelsen 2015. Komiteen for Sundhedsoplysning.

Beddington, J., Cooper, C.L., Field, J., Goswami, U., Huppert, F.A., Jenkins, R., et al. (2008). The mental wealth of nations. Nature, 455, 1057-1060. https://doi.org/10.1038/4551057a

Bendtsen P, M.S., Tolstrup JS. (2015). Ungdomsprofilen 2014. Statens Institut for Folkesundhed, Syddansk Universitet.

Bremne, J.D., \& Vermetten, E. (2001). Stress and development: behavioral and biological consequences. Dev.Psychopathol., 13, 473-489. https://doi.org/10.1017/S0954579401003042

Caspi, A., Houts, R.M., Belsky, D.W., Goldman-Mellor, S.J., Harrington, H., Israel, S., et al. (2014). The p Factor: One General Psychopathology Factor in the Structure of Psychiatric Disorders? Clinical Psychological Science, 2, 119-137. https://doi. org/10.1177/2167702613497473

Danmarks Statistik. Statistikbanken. . (2017). http://www.statistikbanken.dk/statbank5a/ default.asp? $\mathrm{w}=1920$

Due, P., Diderichsen, F., Meilstrup, C., Nordentoft, M., Obel, C., \& Sandbæk, A. (2014). Børn og unges mentale helbred. Vidensråd for Forebyggelse.

Eplov LF, L.S. (2008). Fremme af mental sundhed - baggrund, begreb og determinanter. In F.K. Folker AP, Hamburger L, Hansen JA, Madsen LR, Sindballe AM (Ed.). København: Sundhedsstyrelsen.

Folkeskolens Trivselsmåling. (2016). https://uvm.dk/statistik/grundskolen/elever/trivselsmaalinger.

Fonagy, P., Steele, M., Steele, H., Higgitt, A., \& Target, M. (1994). The Emanuel Miller Memorial Lecture 1992. The theory and practice of resilience. J Child Psychol Psychiatry, 35, 231-257. https://doi.org/10.1111/j.1469-7610.1994.tb01160.x

Helliwell J, L.R., Sachs J (editors) (2017). World Happiness Report 2017.

Keyes, C.L. (2002). The mental health continuum: from languishing to flourishing in life. J Health Soc Behav, 43, 207-222. https://doi.org/10.2307/3090197

Lindholdt L, L.M., Lund T, Hansen CD, Winding TN, Andersen JH. (2017). Alle unge trller. Dokumentationsrapport. Etablering af national ungdomskohorte med henblik på fremtidige forskningsprojekter om unge, helbred og arbejde. foca.

McEwen, B.S. (2016). In pursuit of resilience: stress, epigenetics, and brain plasticity. Annals of the New York Academy of Sciences pp. 56-64). https://doi.org/10.1111/nyas.13020

Rasmussen M, P.T., Due P. (2015). Skolebørnsundersøgelsen 2014. Statens Institut for Folkesundhed, Syddansk Universitet; KØBENHAVN.

Seery, M.D. (2011). Challenge or threat? Cardiovascular indexes of resilience and vulnerability to potential stress in humans. Neuroscience and Biobehavioral Reviews, 35, 16031610. https://doi.org/10.1016/j.neubiorev.2011.03.003

Ungar, M. (2011). The social ecology of resilience: addressing contextual and cultural ambiguity of a nascent construct. Am J Orthopsychiatry, 81, 1-17. https://doi.org/10.1111/j.19390025.2010.01067.x

Ungar, M., Ghazinour, M., \& Richter, J. (2013). Annual Research Review: What is resilience within the social ecology of human development? J Child Psychol Psychiatry, 54, 348-366. https://doi.org/10.1111/jcpp.12025

Ungeprofilundersøgelsen. (2017). https://http://www.ungeprofilen.dk/Public/Default.aspx. 
Waterman, A.S. (1993). Two conceptions of happiness: Contrasts of personal expressiveness (eudaimonia) and hedonic enjoyment. Journal of Personality and Social Psychology, 64, 678-691. https://doi.org/10.1037/0022-3514.64.4.678

Westerhof, G.J., \& Keyes, C.L. (2010). Mental Illness and Mental Health: The Two Continua Model Across the Lifespan. J Adult Dev, 17, 110-119. https://doi.org/10.1007/s10804-0099082-y

WHO. (2014). Mental health: a state of well-being. World Health Organization

Willumsen, G. (2017). Tidlig indsats for sårbare familier. Afdækning af kommunernes indsats til gravide, spæd- og småbørn og deres forældre med udgangspunkt $i$ sundhedsplejens ydelser. Sundhedsstyrelsen København. 